\title{
Air Quality in the Maracanã and Deodoro Zones During the Rio 2016 Olympic Games
}

\author{
Carolina A. Bezerra, ${ }^{a}$ Nicole J. de Carvalho, ${ }^{a}$ Claudio G. P. Geraldino, ${ }^{a}$ \\ Cleyton M. da Silva ${ }^{a, b}$ and Graciela Arbilla*,a
} anstituto de Química, Universidade Federal do Rio de Janeiro, Centro de Tecnologia, Bloco A,
Sala 408, Cidade Universitária, Ilha do Fundão, 21949-900 Rio de Janeiro-RJ, Brazil

${ }^{b}$ Engenharia Ambiental, Universidade Veiga de Almeida, Campus de Maracanã, 20271-020 Rio de Janeiro-RJ, Brazil

\begin{abstract}
The air quality during the Summer 2016 Olympic Games in two Olympic zones, Maracanã (Tijuca) and Deodoro, was studied. Volatile organic compounds (VOCs) were collected and analyzed following method TO-15 (United States Environmental Protection Agency), during and in the days after the Games. The total VOC $\left(\mathrm{C}_{4}-\mathrm{C}_{12}\right)$ concentrations were 39.2-160.9 and 36.6-191.4 $\mu \mathrm{g} \mathrm{m}^{-3}$ for Tijuca and Deodoro, respectively. These concentrations were lower than values previously obtained in Tijuca and other areas of the city. VOC speciation and benzene/ toluene ratios were also different as a consequence of the restrictions imposed on vehicular transit during the Olympic Games. Concentrations were discussed considering the reactivity and ozone forming potential of individual compounds. Criteria pollutants, determined by the Tijuca Automatic Monitoring Station, were also analyzed. The preventive policies were successful in decreasing the concentrations of $\mathrm{CO}$ and $\mathrm{PM}_{10}$, leading to a decrease in mean ozone levels. However, air quality indexes were not dramatically reduced, because of the increase in $\mathrm{NO}_{\mathrm{x}}$ emissions and isolated events of higher ozone levels.
\end{abstract}

Keywords: volatile organic compounds, Rio 2016 Olympic Games, air quality indexes, ozone

\section{Introduction}

The city of Rio de Janeiro is the second largest city in Brazil and has a population of 6.5 million. ${ }^{1}$ It is one of the most visited cities in the Southern Hemisphere, and it is known for its natural settings, beaches, music and events. Since 2014 the city has hosted several international events and, in 2009, it was announced as the host city of the 2016 Summer Olympic Games, officially known as the Games of the XXXI Olympiad and commonly known as Rio 2016. It was the first time that a South American and Portuguesespeaking city hosted the Summer Olympics and the third time the Olympics were held in a Southern Hemisphere city. The Olympic Games were held from August 5 to 21 and the Paralympic Games from September 7 to 18, 2016.

During Rio 2016, the city hosted 1.17 million tourists (410,000 from other countries). In January 2017, the Brazilian Ministry of Tourism confirmed that the Olympic Games helped the country achieve record tourism figures in 2016. Over the twelve months of 2016, Brazil welcomed

*e-mail: gracielaiq@gmail.com
6.6 million foreign tourists, which represented a $4.8 \%$ increase from the previous year, generating a $6.2 \%$ revenue increase. ${ }^{2}$ The competition venues were clustered in four zones: Barra da Tijuca, Copacabana, Deodoro and Maracanã. ${ }^{2}$

The Olympic Games provided a unique opportunity to hasten needed investments in the city to improve transportation, security, education and environmental quality. This potential to generate a wide range of benefits to the population was termed the "Olympic legacy" and included improvements of urban mobility and air quality. Rio de Janeiro invested in several infrastructure projects to improve transportation and the port region. ${ }^{3}$

The air quality was monitored through the automatic monitoring stations of the State and Municipal Governments. ${ }^{4,5}$ In Brazil, the criteria pollutants are smoke, total particulate matter, particulate matter with a diameter of $10 \mu \mathrm{m}$ or less $\left(\mathrm{PM}_{10}\right), \mathrm{SO}_{2}, \mathrm{CO}$, ozone and $\mathrm{NO}_{2}{ }^{6}$ The Brazilian air quality standards (AQS) ${ }^{6}$ as well as the current air quality limits of the United States (US EPA), ${ }^{7}$ European Union $(\mathrm{EU})^{8}$ and World Health Organization Air Quality Guidelines (WHO AQG) ${ }^{9}$ are shown in Table S1 
(Supplementary Information (SI) section). Historical data reported by the State Environmental Agency (INEA) and the Municipal Department of the Environment (SMAC) show that in the city of Rio de Janeiro, $\mathrm{NO}_{2}, \mathrm{PM}_{10}$ and ozone are of major concern; however, in many of the stations, only $\mathrm{PM}_{10}$ and ozone were determined during the Olympic Games. In 2011, the State Environmental Department approved the "Olympic Project" with the objective of increasing the number of automatic monitoring stations and informing the athletes and population of the meteorological and air quality conditions. Eleven new stations were installed in the proximity of the Olympic arenas to determine meteorological parameters and $\mathrm{PM}_{10}$ and ozone concentrations.

During the period from June 2012 to June 2013, Godoy et al..$^{10}$ monitored the levels of $\mathrm{PM}_{10}$ and particulate matter with a diameter of $2.5 \mu \mathrm{m}$ or less $\left(\mathrm{PM}_{2.5}\right)$ at four sampling points in the Rio de Janeiro metropolitan area (Duque de Caxias, Tijuca, Barra de Tijuca and Taquara). As shown in Table S2 (SI section), the authors reported annual means values for $\mathrm{PM}_{10}$ in the interval 25-66 $\mu \mathrm{g} \mathrm{m}^{-3}$. Values for Taquara and Duque de Caxias were higher than the annual national standard $\left(50 \mu \mathrm{g} \mathrm{m}^{-3}\right)$. $\mathrm{PM}_{2.5}$ concentrations at the four sampling points met both the annual and $24 \mathrm{~h}$ WHO AQG. ${ }^{6,9}$

Data obtained in 2013-2015 and published in an INEA's report $^{11}$ showed that in the Copacabana, Maracanã and Deodoro areas, the $\mathrm{PM}_{10}$ levels (24-hour mean) were in the range of 6-96 $\mu \mathrm{g} \mathrm{m}^{-3}$ (Table S2, SI section). These values are below the Brazilian and US EPA standard (24-hour mean, $150 \mu \mathrm{g} \mathrm{m}^{-3}$ ), but above the EU Air Quality Standards (AQS) (24-hour mean, $50 \mu \mathrm{g} \mathrm{m}^{-3}$ ). ${ }^{6-8,12}$ At the Maracanã station, the annual means in 2014 and 2015 were 58 and $61 \mu \mathrm{g} \mathrm{m}^{-3}$, respectively, which is higher than the annual national standard $\left(50 \mu \mathrm{g} \mathrm{m}^{-3}\right){ }^{6} \mathrm{PM}_{2.5}$ is monitored in some new stations, but since it is not a criteria pollutant in Brazil, daily results are not reported to the population. The annual means in 2013, 2014 and 2015 ranged 6-13, 11-20 and 10-14 $\mu^{-3} \mathrm{~m}^{-3}$, respectively, in the five Olympic stations where data were acquired. ${ }^{11}$ These means are high in comparison to the value $10 \mu \mathrm{g} \mathrm{m}^{-3}$ recommended by the WHO. ${ }^{9,13}$ Ozone concentrations from 2013 to 2015 were also high in Deodoro, Maracanã and Copacabana, where the national standard ( $160 \mu \mathrm{g} \mathrm{m}^{-3}$, mean for $1 \mathrm{~h}$ ) was exceeded, mainly in spring and summer, when values as high as $200 \mu \mathrm{g} \mathrm{m}{ }^{-3}$ were obtained. ${ }^{11}$ It is worth noting that the national standard is higher than the values recommended by the EU and the WHO, 78.5 and $98 \mu \mathrm{g} \mathrm{m}^{-3}$, respectively. ${ }^{12}$ The highest values were obtained in Deodoro. In Barra da Tijuca, pollutant concentrations were below the national standards. The 2013-2015 data suggested that the Deodoro and Maracanã areas were the most important in terms of $\mathrm{PM}_{10}$ and ozone concentrations. These data showed that in the years before the Olympic Games, pollutant concentrations were, in general, within the national air standards, but were high in comparison with EU standards ${ }^{8}$ and WHO recommendations. ${ }^{9}$ They also showed that a revision of the standards is required as well as the inclusion of other pollutants, mainly $\mathrm{PM}_{2.5}$.

To achieve the goal of a "green Olympic Games", the government also adopted policies to reduce emissions before and during the Olympic Games, in the period between the Olympic and the Paralympic Games and during the Paralympic Games: holidays in schools and universities in August 2016, access to all venues exclusively by public transport, freight delivery restrictions in terms of time and area and driving restrictions for vehicles in certain areas and roads.

Similar policies were adopted in the 2008 and 2012 Olympic Games. In Beijing, a series of aggressive pollution control measures were implemented from July 20 to September 17, 2008, encompassing the entire Olympic and Paralympic Games, that limited the operation of industrial and commercial combustion facilities and imposed alternate-day driving to remove approximately one-half of the cars from the roads each day. After the Paralympics, these pollution control actions were relaxed. ${ }^{14}$ For London 2012, the preparation included improved public and alternative transport and the development of green areas for physical activity and cycling. However, the planning did not predict fewer motor vehicles after the Games or an increase in public health and living conditions for the population. ${ }^{15}$ In general, it was observed that the "Olympic legacy" was, in these cities, very limited in terms of air quality.

In Rio de Janeiro, despite the implementation of new automatic monitoring stations, the investment was still insufficient. The criteria pollutant $\mathrm{NO}_{2}$ was not determined in the new stations. ${ }^{4,11,16}$ Also, volatile organic compounds (VOCs) were not monitored because they are not considered in Brazilian legislation. ${ }^{6} \mathrm{NO}_{\mathrm{x}}\left(\mathrm{NO}_{\mathrm{x}}=\mathrm{NO}+\mathrm{NO}_{2}\right)$ and some VOCs have a negative impact on public health, ${ }^{17}$ notably benzene, which is a known human carcinogen..$^{18}$ They also play a central role in tropospheric ozone production. ${ }^{19} \mathrm{As}$ was thoroughly described by Atkinson, ${ }^{19}$ in the troposphere, VOCs are removed by the physical processes of wet and dry deposition and are transformed by the chemical processes of photolysis and reaction with hydroxyl radicals $(\bullet \mathrm{OH})$, nitrate radicals $\left(\mathrm{NO}_{3}\right)$ and ozone. Reactions with $\bullet \mathrm{OH}$ radicals are responsible for most VOCs consumption. The hydroxyl radical reacts with anthropogenic and biogenic VOCs, forming intermediate radicals $\left(\bullet \mathrm{RO}_{2}\right.$ and $\left.\bullet \mathrm{HO}_{2}\right)$, which react with $\mathrm{NO}$ converting it to $\mathrm{NO}_{2}$. $\mathrm{NO}_{2}$ decomposes 
photochemically forming $\mathrm{O}\left({ }^{3} \mathrm{P}\right)+\mathrm{NO}$. The reaction of $\mathrm{O}\left({ }^{3} \mathrm{P}\right)$ with $\mathrm{O}_{2}$ is the only known anthropogenic source of tropospheric ozone. ${ }^{19,20}$ Ozone may also react with VOCs and, in the absence or low concentrations of $\mathrm{NO}$, may react with $\bullet \mathrm{OH}$ and $\bullet \mathrm{HO}_{2}$ radicals. Net photochemical formation of $\mathrm{O}_{3}$ versus net photochemical loss of $\mathrm{O}_{3}$ in the troposphere, therefore, depends on the NO concentration and also on the reactivity of the VOC mixture. ${ }^{19}$ Then, the determination and speciation of VOCs, as well as the $\mathrm{VOC} / \mathrm{NO}_{\mathrm{x}}$ ratios, are necessary to understand ozone levels and to manage air quality policies. ${ }^{21}$

Recently, a determination of total particulate matter, semi-volatile organic compounds and BTEX (benzene, toluene, ethylbenzene and xylenes) in urban areas near the Rio de Janeiro Olympic Games sites were published. ${ }^{22}$ BTEX were collected in adsorbent tubes and determined by gas-chromatography. Data were obtained in 2014, two years before the Games, and the authors reported that the Maracanã zone was the most polluted area.

Air quality indexes (AQIs) determined in Rio de Janeiro from July-September 2016, before and during the Summer Olympic and Paralympic Games, by monitoring stations operated by the SMAC, were compiled and analyzed by Tsuruta et al. ${ }^{23} \mathrm{NO}_{2}$ and $\mathrm{PM}_{10}$ levels were generally lower during the Olympic period because of restrictions on vehicular flux. However, ozone concentrations remained high, ${ }^{23}$ and a further study seems necessary to analyze the concentrations of ozone precursors and unfavorable meteorological conditions.

In this work, the air quality during the Games was studied using several approaches: first, concentrations of non-oxygenated VOCs were determined, in the two Olympic zones, Deodoro and Maracanã, that had registered higher ozone levels in 2013-2015. VOC concentrations were discussed in terms of reactivity and ozone forming potential and, also, using a simple air quality model and compared with values obtained in 2015. Then, reported AQIs and data for criteria pollutants, obtained by the SMAC monitoring station in Tijuca (Maracanã zone), during and before the Games, were also analyzed to verify the effect of preventive policies. These data are, to the best of our knowledge, the only report of volatile organic compounds concentrations during the Rio 2016 Olympic Games.

\section{Experimental}

\section{Sampling sites}

Rio de Janeiro is a coastal city located on the western shore of Guanabara Bay, near $22^{\circ} 54^{\prime} \mathrm{S}$ and $43^{\circ} 12^{\prime} \mathrm{W}$, at an altitude of approximately $10 \mathrm{~m}$ in relation to the mean sea level. According to the Köppen climate classification system, ${ }^{24}$ its climatic condition is Atlantic tropical (Aw), characterized by being megathermal with an average air temperature of $16{ }^{\circ} \mathrm{C}$ throughout the year and having a dry season (from April to September) in which the average monthly precipitation is less than $60 \mathrm{~mm}$ for at least one month of the year. The annual relative humidity average varies between 70 and $80 \%$, with no significant variation during the year. ${ }^{24}$ Air circulation in the metropolitan area is significantly affected by topographical conditions. The Tijuca Forest, which is a mountainous rainforest area, forms a natural barrier to air circulation and divides the city into northern and southern sections.

Air samples were collected from August 17 to September 5, 2016. The sampling locations were the Olympic zones of Deodoro and Maracanã. During the sampling period, the temperature varied between 15.8 and $38.3^{\circ} \mathrm{C}$, and the total precipitation was $53 \mathrm{~mm} \cdot{ }^{25} \mathrm{~A}$ map of the city with the sampling locations and the Maracanã and Deodoro Olympic zones is presented as SI section in Figure S1.

\section{Deodoro Olympic zone}

The Deodoro zone lies in the west of the city and contained the Whitewater Stadium (canoe slalom); the Olympic Mountain Bike, MBX, Shooting, Equestrian and Hockey centers; the Youth Arena and the Deodoro Stadium. ${ }^{2}$ The sampling location (22 51 '22.00' S; $43^{\circ} 23^{\prime} 13.90^{\prime \prime} \mathrm{W}$ ) was approximately equidistant to all these arenas (1.5-2.0 km). The district is a residential and military area, with heavy transit of diesel military vehicles. The main avenue, Duque de Caxias, has four lanes and was partially closed during the Olympic Games. During the morning, west/southwest winds are predominant. The northeastern component increases throughout the day until the late afternoon, and from then until the evening, northeast/southeast winds are more frequent. ${ }^{24}$

\section{Maracanã Olympic zone}

The Maracanã Stadium, in the northern area of the city, hosted the Opening and Closing Ceremonies as well as the football finals (plus one men's and one women's semi-final). Meanwhile, the Olympic Stadium, another of the football venues, also provided the setting for the track and field events, while the Maracanãzinho hosted the volleyball competition. ${ }^{2}$ The Maracanã Stadium is approximately $12 \mathrm{~km}$ from downtown and the port area, which was renovated and hosted the Olympic Boulevard, museums, the Olympic torch and many leisure activities. 
The stadium is also near Quinta da Boa Vista, a public park, where the National Museum and the Zoological Garden of Rio de Janeiro are located. Samples were collected in Saens Peña Square, Tijuca (22 ${ }^{\circ} 55^{\prime} 30.07^{\prime}$ 'S; 4313'57.33'” W), approximately $1.9 \mathrm{~km}$ from the Maracanã Stadium. The area has a high flux of vehicles and people caused by the intensive commercial activities around the region, a subway station, several medical and shopping centers, restaurants, bars and leisure activities. An air quality monitoring station, operated by SMAC, is located in the sampling area and provides $10 \mathrm{~min}$ average $\mathrm{O}_{3}, \mathrm{CO}$ and $\mathrm{NO}_{x}$ concentrations, meteorological parameters and solar radiation. The atmospheric emissions of the studied area are mainly from vehicular sources due to the high flux of vehicles. Due to the proximity of the rainforest mountains, maritime breezes do not reach this area. Weak mountain breezes from the south and southwest are the most frequent, and the region is poorly ventilated. ${ }^{26}$ The wind rose calculated for August and September 2016, with data provided by the monitoring station, is presented in the SI section (Figure S2).

$\mathrm{PM}_{10}$ and ozone concentrations were also determined in the Olympic automatic monitoring stations of Maracanã (22 54'36.07' 'S; 43 14 '14.52'”W) and Campo dos Afonsos (22 52 ' 41.74 ' $\mathrm{S}$; $\left.43^{\circ} 22^{\prime} 42.98^{\prime \prime} \mathrm{W}\right)$, operated by INEA. These stations did not monitor $\mathrm{NO}_{\mathrm{x}}$ concentrations and the meteorological parameters were not available. ${ }^{11,16}$ Both the Maracanã and Saens Peña Square (Tijuca) stations (where the VOCs were sampled) are in the Maracanã zone and are approximately $1.5 \mathrm{~km}$ apart. Campo dos Afonsos is in the Deodoro zone and is approximately $2.5 \mathrm{~km}$ from the VOC sampling location.

\section{Sampling and analysis}

VOCs were sampled and analyzed using method TO-15 (US EPA), ${ }^{27}$ during the early morning hours (8:00-9:00 a.m.), which have high vehicle traffic and low photochemical activity. Samples were collected at a standard sampling height of $1.0 \mathrm{~m}$ using $6 \mathrm{~L}$ stainless steel canisters (Restek Silonite ${ }^{\circledR}$, USA) with TOV-2 ${ }^{\mathrm{TM}}$ valves and a flux restrictor (Entech Flow Controller CS1200E with a Silonite ${ }^{\circledR}$ filter, USA) to meet a final pressure of $1 \mathrm{~atm}$ and a sampling time of $60 \mathrm{~min}$. Before sampling, the canisters were cleaned following the procedures outlined in method TO- $15^{27}$ using a cleaning system (RM Environmental Systems Inc., model 960, CA, USA). Briefly, all canisters were evacuated to $500 \mathrm{mTorr}$ at $120^{\circ} \mathrm{C}$ and maintained in vacuum for $60 \mathrm{~min}$. Then, the canisters were filled with humidified $\mathrm{He}$ (50\% relative humidity) to $30 \mathrm{psig}$. This cycle was completed three more times for a total of four cycles; then, four additional cycles were completed with dry He. Blank samples were generated by pressurizing the clean canisters with He. The canisters were considered clean if less than $0.2 \mathrm{ng}$ of each target compound was detected. Then, the canisters were evacuated below 5 mTorr prior to use.

After the sampling, the canisters were taken back to the laboratory and the samples were analyzed within 3 days of sampling on a gas chromatograph with a thermal desorption and mass spectrometer detection (GC-MS-TD) system (Agilent, model GC 7890A, MS 5975C, CA, USA and Markes CIA Advanced, OH, USA) according to the TO-15 method. ${ }^{27}$ In the analysis of a sample, $500 \mathrm{~mL}$ of the air sample was directed from the canister (flow rate of $20 \mathrm{~mL} \mathrm{~min}^{-1}$ ) through a Nafion dryer trap to reduce the water vapor content below any threshold affecting the proper operation of the analytical system. It was then directed through a cold trap containing carbon molecular sieves (Markes U-T3ATX-2S, USA) at $-10^{\circ} \mathrm{C}$ to retain the VOCs. The VOCs were thermally desorbed $\left(300{ }^{\circ} \mathrm{C}\right)$ and transferred to a DB-624 gas chromatographic column for separation $(60 \mathrm{~m} \times 0.32 \mathrm{~mm} \times 1.80 \mu \mathrm{m})$. He $5.0(99.999 \%$, ultra-high purity grade) was used as the carrier gas at a constant flow of $3.5 \mathrm{~mL} \mathrm{~min}^{-1}$. The oven temperature program was set as follows: $25^{\circ} \mathrm{C}$ for $5 \mathrm{~min}, 25$ to $50{ }^{\circ} \mathrm{C}$ at $0.8{ }^{\circ} \mathrm{C} \mathrm{min}-1,50$ to $250{ }^{\circ} \mathrm{C}$ at $5{ }^{\circ} \mathrm{C} \mathrm{min}{ }^{-1}$ and $250{ }^{\circ} \mathrm{C}$ for $3 \mathrm{~min}$. The injector temperature was $190{ }^{\circ} \mathrm{C}$. Each VOC was identified by matching the retention time and mass spectrum of the unknown compound with those of the standard reference mixture. Both scan mode and selective ion monitoring (SIM) of the most abundant ions were used to ensure the correct identification of all compounds. Quantification was performed using selective ion monitoring (SIM) of the most abundant ions, based on an external analytical curve using a standard reference mixture that covered the entire concentration range of the ambient samples (57 compounds, Restek, 20-60 ppbC, p/n 34445, PA, USA). The calculated determination coefficients for all of the VOCs were greater than 0.99. All samples were measured in triplicate, and a difference of less than $25 \%$ was considered acceptable, as stated in the TO- 15 method. ${ }^{27}$ The limits of detection (LOD) and quantification (LOQ), which were calculated from the noise standard deviation, were 0.2 and $0.6 \mathrm{ng}$, respectively, for all of the compounds. Other details of the implementation and validation of the method were previously discussed. ${ }^{28,29}$

\section{Criteria pollutant analysis}

Detailed $\mathrm{PM}_{10}$ and ozone concentrations determined at the INEA Olympic monitoring stations (Maracanã and Campo dos Afonsos, Deodoro) were not available. ${ }^{16}$ INEA 
published a daily air quality bulletin reporting the AQI for $24 \mathrm{~h}$. This index was proposed by the São Paulo State Environmental Agency and is used in several Brazilian cities. ${ }^{30}$ This index was introduced to comparatively assess the air pollution in the monitored areas and should be calculated based on the highest index for several compounds $\left(\mathrm{PM}_{10}, \mathrm{SO}_{2}, \mathrm{O}_{3}, \mathrm{NO}_{2}\right.$ and $\left.\mathrm{CO}\right)$ from 3:00 p.m. of the previous day to 3:00 p.m. of the target day. The index has a five-step scale from very low $(0-50)$ to very severe $(>300)$ pollution. The concentration ranges and health implications of each level are shown in the SI section (Table S3).

Daily AQIs reported from the Campo dos Afonsos (Deodoro), Maracanã and Tijuca automatic monitoring stations were compiled and analyzed to determine the pollutants of major concern. ${ }^{5,16}$ Additionally, the individual concentrations (CO, $\mathrm{NO}_{\mathrm{x}}, \mathrm{PM}_{10}$ and ozone) determined by SMAC were compiled and displayed in the form of box-plot diagrams and concentration versus day of sampling, ${ }^{5}$ using code written in the $\mathrm{R}$ language (version 3.3.1) ${ }^{31}$ to compare the sampling locations and the three-month periods. Meteorological data, when available, were provided by the automatic monitoring stations.

\section{Results and Discussion}

\section{VOC concentrations}

Air samples were collected in two Olympic zones, Maracanã (Tijuca) (14 samples) and Deodoro (13 samples). Considering the 50 non-oxygenated VOCs $\left(\mathrm{C}_{4}-\mathrm{C}_{12}\right)$ that were determined using the TO- 15 method, ${ }^{27}$ the total VOC masses were 39.2-160.9 and 36.6-191.4 $\mu \mathrm{g} \mathrm{m}^{-3}$ in Tijuca and Deodoro, respectively. The mean values were 89.9 and $98.8 \mu \mathrm{g} \mathrm{m}^{-3}$ for Tijuca and Deodoro, respectively. Since only non-oxygenated $\mathrm{C}_{4}-\mathrm{C}_{12}$ compounds were determined, these values are a lower estimation of total VOC levels in the studied locations. Other compounds, such as $\mathrm{C}_{2}-\mathrm{C}_{3}$ VOCs, formaldheyde and acetaldheyde, may have an important contribution to ozone formation, but could not be determined using TO-15 method as implemented in this work. ${ }^{29}$

The mean and median concentrations, standard deviations, and minimum and maximum values for the determined VOCs at each sampling location are presented in Table 1. 1,3,5-Trimethylbenzene concentrations were below LOD in all samples. $m$-Xylene and $p$-xylene values are reported as the sum of concentrations for both compounds.

In a previous monitoring campaign performed in the same period, one year before the Olympic Games, samples were collected in Tijuca at the same location and under the same conditions. Total VOC concentrations were 117.8-431.7 $\mu \mathrm{g} \mathrm{m}{ }^{-3}$ for $\mathrm{C}_{4}-\mathrm{C}_{12}$ compounds. ${ }^{32}$ According to the Rio de Janeiro emission inventory, approximately $73 \%$ of non-methane hydrocarbons are emitted by light vehicles. ${ }^{33}$ Thus, lower total VOC concentrations were expected for the 2016 study period since the flux of light vehicles in this period was reduced because of the holidays in schools, universities and other public offices; the access to all venues being exclusively by public transport; and the driving restrictions for vehicles in certain areas and streets. Mean concentrations of isoprene, the major biogenic compound, were 1.5 and $1.3 \mu \mathrm{g} \mathrm{m}^{-3}$ in 2015 and 2016,,32 respectively, indicating that the lower total VOC concentrations were due to a reduction in anthropogenic emissions.

The total mean VOC concentrations (89.87 and $98.77 \mu \mathrm{g} \mathrm{m}^{-3}$ ) obtained in this work were also lower than the mean value $\left(275.9 \mu \mathrm{g} \mathrm{m}^{-3}\right)$ previously obtained for sixteen canisters collected along the main streets of the city of Rio de Janeiro during 2012 using the same method and considering the same non-oxygenated VOCs $\left(\mathrm{C}_{4}-\mathrm{C}_{12}\right)$. Values for individual samples were from 197.1-628.8 $\mu \mathrm{g} \mathrm{m}^{-3} .{ }^{34}$ In the pre-Olympic period, July 12-August 2, 2016, samples were collected in Bangu District, a neighborhood in the northern area of the city, and the mean total VOC concentration determined using the TO-15 method for 52 non-oxygenated VOCs $\left(\mathrm{C}_{3}-\mathrm{C}_{12}\right)$ was $173.3 \mu \mathrm{g} \mathrm{m}^{-3}$, with individual values of 53.6-421.3 $\mu \mathrm{g} \mathrm{m} \mathrm{m}^{-3} .{ }^{35}$ The mean $\mathrm{C}_{3}$ mass (propane and propene) determined in Bangu was $25.8 \mu \mathrm{g} \mathrm{m}^{-3}$, resulting in a total mean VOCs $\left(\mathrm{C}_{4}-\mathrm{C}_{12}\right)$ concentration of $147.5 \mu \mathrm{g} \mathrm{m}^{-3}$, which is also higher than the mean values determined in this study.

Benzene concentrations were from 1.05 to 3.05 and 0.74 to $4.99 \mu \mathrm{g} \mathrm{m}^{-3}$ for Tijuca and Deodoro, respectively. The Ambient Air Quality and Cleaner Air for Europe, CAFE Directive 2008/50/EC limit value, ${ }^{8}$ to be attained until January 2010, was specified as $5 \mu \mathrm{g} \mathrm{m}^{-3}$ to protect human health. The mean values determined in this work (1.81 and $2.26 \mu \mathrm{g} \mathrm{m}^{-3}$ for Tijuca and Deodoro, respectively) as well as the individual concentrations were below this limit. Benzene values determined in the Olympic zones, two years before the Olympic Games, were in the interval 3.01-8.82 $\mu \mathrm{g} \mathrm{m}^{-3} .{ }^{22}$

The benzene/toluene ratios obtained in Tijuca were $0.39-0.82$, with a mean value of 0.50 . These values are approximately twice those obtained in the same location in 2015 (ranging from 0.14 to 0.34 ), ${ }^{32}$ and higher than those obtained using the TO-1 method in the same sampling location (0.23) and on Brazil Avenue (0.21) ${ }^{36,37}$ In view of these previous data obtained in Rio de Janeiro, values lower than 0.35 could be considered characteristic of the 
Table 1. Mean and median concentrations, standard deviation (sd), and minimum and maximum values for the determined VOCs in Tijuca and Deodoro

\begin{tabular}{|c|c|c|c|c|c|c|c|c|c|c|}
\hline \multirow{2}{*}{ Compound } & \multicolumn{5}{|c|}{ Tijuca / $\left(\mu \mathrm{g} \mathrm{m}^{-3}\right)$} & \multicolumn{5}{|c|}{ Deodoro / $\left(\mu \mathrm{g} \mathrm{m}^{-3}\right)$} \\
\hline & Mean & $\mathrm{sd}$ & Median & Minimum & Maximum & Mean & $\mathrm{sd}$ & Median & Minimum & Maximum \\
\hline Isobutane & 11.88 & 6.20 & 11.93 & 3.90 & 23.28 & 12.99 & 8.69 & 11.11 & 3.92 & 26.79 \\
\hline$n$-Butane & 21.50 & 11.38 & 21.31 & 7.28 & 43.55 & 22.00 & 14.53 & 19.03 & 6.58 & 46.62 \\
\hline 2,2-Dimethylbutane & 0.34 & 0.26 & 0.25 & 0.04 & 0.88 & 0.32 & 0.25 & 0.23 & 0.04 & 0.81 \\
\hline Isopentane & 10.27 & 6.74 & 6.21 & 3.50 & 21.48 & 11.24 & 6.83 & 8.10 & 3.63 & 21.31 \\
\hline$n$-Pentane & 9.01 & 5.62 & 5.87 & 3.28 & 19.30 & 10.04 & 5.22 & 7.36 & 3.76 & 17.86 \\
\hline 2,3-Dimethylbutane & 0.75 & 0.41 & 0.76 & 0.24 & 1.55 & 0.83 & 0.48 & 0.58 & 0.36 & 1.68 \\
\hline 2-Methylpentane & 2.32 & 1.47 & 1.43 & 0.95 & 4.78 & 2.98 & 2.08 & 2.22 & 0.96 & 6.50 \\
\hline 3-Methylpentane & 1.56 & 0.91 & 1.23 & 0.63 & 2.93 & 2.07 & 1.48 & 1.40 & 0.69 & 4.73 \\
\hline$n$-Hexane & 2.85 & 1.56 & 2.24 & 1.17 & 5.50 & 3.67 & 2.68 & 2.72 & 1.14 & 8.09 \\
\hline 2,4-Dimethylpentane & 0.32 & 0.34 & 0.21 & 0.00 & 1.14 & 0.32 & 0.31 & 0.18 & 0.02 & 0.94 \\
\hline Methylcyclopentane & 1.14 & 0.68 & 0.92 & 0.46 & 2.24 & 1.43 & 0.97 & 1.08 & 0.50 & 2.97 \\
\hline Isooctane & 0.12 & 0.13 & 0.05 & 0.00 & 0.35 & 0.14 & 0.23 & 0.01 & 0.00 & 0.53 \\
\hline 2,3,4-Trimethylpentane & 0.11 & 0.11 & 0.08 & 0.00 & 0.27 & 0.34 & 0.05 & 0.34 & 0.30 & 0.38 \\
\hline Cyclohexane & 0.68 & 0.33 & 0.57 & 0.30 & 1.32 & 0.72 & 0.44 & 0.53 & 0.33 & 1.60 \\
\hline 2-Methylhexane & 0.79 & 0.49 & 0.58 & 0.33 & 1.82 & 0.83 & 0.57 & 0.65 & 0.27 & 1.97 \\
\hline 2,3-Dimethylpentane & 0.24 & 0.25 & 0.16 & 0.01 & 0.79 & 0.32 & 0.27 & 0.20 & 0.00 & 0.77 \\
\hline 3-Methylhexane & 0.98 & 0.61 & 0.69 & 0.45 & 2.13 & 1.01 & 0.72 & 0.73 & 0.30 & 2.26 \\
\hline$n$-Heptane & 1.29 & 0.76 & 0.99 & 0.61 & 2.61 & 1.51 & 1.03 & 1.09 & 0.50 & 3.34 \\
\hline Methylcyclohexane & 0.68 & 0.43 & 0.45 & 0.29 & 1.66 & 0.80 & 0.63 & 0.51 & 0.21 & 1.98 \\
\hline 2-Methylheptane & 0.39 & 0.23 & 0.31 & 0.15 & 0.77 & 0.45 & 0.37 & 0.31 & 0.08 & 1.14 \\
\hline 3-Methylheptane & 0.26 & 0.18 & 0.16 & 0.08 & 0.58 & 0.27 & 0.26 & 0.16 & 0.03 & 0.75 \\
\hline$n$-Octane & 0.54 & 0.32 & 0.36 & 0.26 & 1.09 & 0.61 & 0.45 & 0.46 & 0.15 & 1.33 \\
\hline$n$-Nonane & 0.35 & 0.26 & 0.26 & 0.09 & 1.00 & 0.39 & 0.36 & 0.24 & 0.03 & 0.91 \\
\hline$n$-Decane & 0.47 & 0.37 & 0.34 & 0.06 & 1.36 & 0.36 & 0.31 & 0.25 & 0.01 & 0.88 \\
\hline Undecane & 0.81 & 0.79 & 0.49 & 0.26 & 2.54 & 0.46 & 0.42 & 0.44 & 0.09 & 0.86 \\
\hline Dodecane & 0.80 & 0.59 & 0.62 & 0.32 & 2.64 & 0.57 & 0.20 & 0.51 & 0.35 & 0.93 \\
\hline Benzene & 1.81 & 0.81 & 1.50 & 1.05 & 3.32 & 2.26 & 1.77 & 1.33 & 0.74 & 5.20 \\
\hline Toluene & 3.64 & 1.98 & 2.53 & 2.06 & 7.69 & 5.55 & 5.53 & 3.43 & 1.57 & 18.64 \\
\hline Ethylbenzene & 0.53 & 0.29 & 0.40 & 0.25 & 1.10 & 0.62 & 0.47 & 0.47 & 0.18 & 1.36 \\
\hline Cumene & 0.17 & 0.13 & 0.14 & 0.04 & 0.38 & N.D. & 0.03 & N.D. & N.D. & 0.11 \\
\hline$n$-Propylbenzene & 0.16 & 0.13 & 0.13 & 0.02 & 0.52 & 0.12 & 0.10 & 0.09 & 0.00 & 0.31 \\
\hline$(m+p)$-Xylene & 0.64 & 0.38 & 0.42 & 0.31 & 1.32 & 0.75 & 0.53 & 0.57 & 0.27 & 1.67 \\
\hline$o$-Xylene & 0.35 & 0.27 & 0.22 & 0.10 & 0.88 & 0.40 & 0.37 & 0.30 & 0.04 & 1.06 \\
\hline Styrene & 0.92 & 0.06 & 0.92 & 0.83 & 1.04 & 1.02 & 0.24 & 0.90 & 0.85 & 1.57 \\
\hline 1-Ethyl-4-methylbenzene & 0.50 & 0.21 & 0.44 & 0.26 & 1.02 & 0.47 & 0.24 & 0.36 & 0.22 & 0.92 \\
\hline 1-Ethyl-3-methylbenzene & 0.31 & 0.14 & 0.29 & 0.16 & 0.69 & 0.28 & 0.13 & 0.22 & 0.15 & 0.53 \\
\hline 1,2,3-Trimethylbenzene & 0.27 & 0.31 & 0.15 & 0.03 & 0.87 & N.D. & 0.15 & 0.27 & 0.03 & 0.31 \\
\hline 1-Ethyl-2-methylbenzene & 0.16 & 0.18 & 0.10 & 0.01 & 0.52 & N.D. & 0.10 & 0.06 & 0.02 & 0.22 \\
\hline 1,2,4-Trimethylbenzene & 0.36 & 0.30 & 0.28 & 0.06 & 1.15 & 0.34 & 0.35 & 0.15 & 0.02 & 1.02 \\
\hline 1,3-Diethylbenzene & 0.44 & 0.60 & 0.23 & 0.01 & 2.23 & 0.25 & 0.33 & 0.14 & 0.04 & 0.99 \\
\hline$p$-Diethylbenzene & 0.54 & 0.58 & 0.33 & 0.09 & 1.65 & N.D. & 0.11 & 0.58 & 0.50 & 0.66 \\
\hline 2-Methyl-1,3-butadiene & 1.31 & 0.70 & 1.02 & 0.59 & 2.46 & 0.90 & 0.48 & 0.73 & 0.29 & 1.70 \\
\hline 1-Butene & 1.91 & 0.55 & 1.83 & 1.01 & 2.81 & 3.27 & 2.35 & 1.98 & 1.19 & 8.21 \\
\hline 1-Pentene & 0.58 & 0.16 & 0.58 & 0.35 & 0.84 & 0.62 & 0.19 & 0.58 & 0.41 & 0.98 \\
\hline 1-Hexene & 1.35 & 0.32 & 1.31 & 0.94 & 1.93 & 1.34 & 0.39 & 1.24 & 0.98 & 2.24 \\
\hline trans-2-Butene & 1.15 & 0.49 & 1.07 & 0.39 & 1.95 & 1.37 & 0.73 & 1.00 & 0.65 & 2.82 \\
\hline cis-2-Butene & 0.83 & 0.31 & 0.91 & 0.31 & 1.40 & 1.06 & 0.57 & 0.95 & 0.52 & 2.27 \\
\hline cis-2-Pentene & 0.58 & 0.23 & 0.56 & 0.24 & 1.02 & 0.58 & 0.28 & 0.47 & 0.22 & 1.15 \\
\hline trans-2-Pentene & 0.90 & 0.44 & 0.80 & 0.35 & 1.60 & 0.91 & 0.46 & 0.73 & 0.37 & 1.82 \\
\hline Total VOC abundance / $\left(\mu \mathrm{g} \mathrm{m}^{-3}\right)$ & 89.87 & & 74.60 & & & 98.77 & & 77.00 & & \\
\hline
\end{tabular}


local fleet under current conditions, which uses ethanol and ethanol-blended gasoline (light vehicles) and diesel with $7 \%$ biodiesel (buses) as fuels. In 2014, during the FIFA 2014 World Cup, Souza et al. ${ }^{38}$ obtained a ratio of 0.39 . The benzene/toluene emission ratio has been previously reported for the diesel and biodiesel blends (B2 to B20) currently used in Brazil to be 0.50-0.60. ${ }^{39}$ The observed increase in this ratio is a consequence of the changes in the fleet composition during the Olympic Games, with an increase in the use of public transportation (subway and buses) instead of private cars.

All these results, indicate that the concentration of the measured VOCs was lower during the 2016 Olympic Games than in previous years. Since all the results were obtained during the early morning, when the photochemical activity is lower, it can be considered a direct consequence of the restrictions in vehicular emissions.

Results can also be compared with those obtained in 2008 Beijing Olympic Games. Liu et al. ${ }^{18}$ determined the hourly concentrations of BTEX (benzene, toluene, ethylbenzene, $m+p$-xylene and $o$-xylene) in the urban area of Beijing during July-October 2008, covering the periods of the 2008 Olympic and Paralympic Games. During the Games, the mean daytime (6:00 a.m. to 8:00 p.m.) concentrations of benzene, toluene, ethylbenzene, $m+p$-xylene and $o$-xylene were 2.37, 3.97, 1.92, 3.51 and $1.90 \mu \mathrm{g} \mathrm{m}^{-3}$, respectively, and these values were $52.8,63.9$, $56.4,56.8$ and $46.9 \%$ lower than those after the Beijing Games. Despite the sampling period and the sampling and analysis methods being different, it is worth noting that the benzene and toluene levels determined in this work were in the same range as those determined in Beijing. The results for benzene, toluene and xylenes are also in the same range as those determined during the Beijing Olympic Games (August 2008) at the Chinese Research Academy of Environmental Sciences ${ }^{40}$ but the total VOC concentration was approximately twice than that reported by Wang et al. ${ }^{40}$ for Beijing.

\section{VOCs reactivity study}

The atmospheric roles of individual VOCs were evaluated considering their reactivities toward hydroxyl radicals $(\bullet \mathrm{OH})$ and their contribution in the formation of ozone, in the studied scenarios. Compounds were ranked considering their mass abundance and reactivity in order to assess their importance in ozone production.

The kinetic and the incremental reactivity of the individual VOCs were evaluated..$^{28,29,35}$ The kinetic reactivity was evaluated as the product of the concentration of an individual VOC and the rate coefficient $\left(\mathrm{k}_{\mathrm{OH}}\right)$ for the reaction of the target compound with $\bullet \mathrm{OH}$ radicals, using literature $\mathrm{k}_{\mathrm{OH}}$ values. ${ }^{41}$ This scale is based on the fact that the reactions of VOCs with $\bullet \mathrm{OH}$ radicals are responsible for the consumption of most VOCs and lead to the production of free radicals $\left(\bullet \mathrm{HO}_{2}, \bullet \mathrm{RO}_{2}\right)$, which oxidize $\mathrm{NO}$ to $\mathrm{NO}_{2}$ and cause ozone formation. In order to evaluate the incremental reactivity, the maximum incremental reactivity (MIR) coefficients that Carter proposed are typically used. ${ }^{41,42}$ In this work, the incremental reactivity was calculated as the product of the concentration $\left(\mu \mathrm{g} \mathrm{m}^{-3}\right)$ and the reactivity coefficients (dimensionless) in three scales: MIR, MOIR (maximum ozone incremental reactivity) and EBIR (equal benefit incremental reactivity). As described by Carter, ${ }^{41}$ MIR coefficients were calculated for typical urban conditions with high $\mathrm{NO}_{\mathrm{x}}$ concentrations and $\mathrm{VOC} / \mathrm{NO}_{\mathrm{x}}$ ratios less than 4 (in units of ppmC and ppm, for VOC and $\mathrm{NO}_{x}$, respectively), yielding the highest ozone concentrations. The MOIR scale represents lower $\mathrm{NO}_{x}$ conditions (a VOC/NO $\mathrm{Natio}_{\mathrm{x}}$ approximately 5.6), and the EBIR scale (a VOCs/ $\mathrm{NO}_{\mathrm{x}}$ ratio of approximately 9) represents even lower $\mathrm{NO}_{x}$ conditions, where the $\mathrm{NO}_{x}$ and VOC controls are equally effective in reducing ozone formation.

The top 15 compounds, considering the kinetic and incremental reactivity of the VOCs, are shown in Table 2. The top 15 compounds, when considering mass abundance, are also shown. Considering the 50 analyzed VOCs, the compounds listed in Table 2 can form a list of 21 compounds (the same compounds for Tijuca and Deodoro), which account for $>79 \%$ of the contribution in each of the considered scales: $n$-butane, isobutane, isopentane, $n$-pentane, $n$-hexane, $n$-heptane, 2-methylpentane, 3-methylpentane, methylcyclopentane, toluene, benzene, $(m+p)$-xylene, styrene, 1-butene, trans-2-butene, cis-2-butene, 1-pentene, trans-2-pentene, cis-2-pentene, 1-hexene, butadiene and isoprene.

For the present study in Tijuca, isoprene, 1-butene, $n$-pentane, toluene, $n$-butane, isobutane, isopentane, $n$-hexane, 1-hexene and trans-2-butene were within the top 15 compounds in the five ranking lists. cis-2-Butene, transand cis-2-pentene, 1-pentene, styrene, 2-methylpentane and xylenes were only important in the reactivity scales.

In the previous monitoring campaign performed in the same period, one year before the Olympic Games, the compounds in the five top 15 lists were 1 -butene, $n$-pentane, toluene, $n$-butane, isopentane and $n$-hexane. The difference between the results obtained in 2015 and 2016 suggests a change in the emissions, probably due to the differences in the traffic flux (the fleet composition and the circulation conditions). ${ }^{32}$

For the present study in Deodoro, $n$-butane, isobutane, isopentane, $n$-pentane, toluene, $n$-hexane, 1 -butene, 
Table 2. Top 15 compounds considering their mass abundance and kinetic and incremental reactivity for the two sampling locations (Tijuca and Deodoro)

\begin{tabular}{|c|c|c|c|c|}
\hline \multirow{2}{*}{ Mass abundance } & \multirow{2}{*}{ Kinetic reactivity $\left(\mathrm{k}_{\mathrm{OH}}\right)$} & \multicolumn{3}{|c|}{ Mechanistic reactivity } \\
\hline & & MIR & MOIR & EBIR \\
\hline \multicolumn{5}{|c|}{ Tijuca (Maracanã zone) } \\
\hline$n$-Butane & isoprene & $n$-butane & $n$-butane & $n$-butane \\
\hline Isobutane & trans-2-butene & 1-butene & isopentane & isopentane \\
\hline Isopentane & trans-2-pentene & trans-2-butene & isobutane & isobutane \\
\hline$n$-Pentane & 1-butene & isopentane & $n$-pentane & $n$-pentane \\
\hline Toluene & styrene & isobutane & 1-butene & 1-butene \\
\hline$n$-Hexane & $n$-butane & toluene & trans-2-butene & trans-2-butene \\
\hline 2-Methylpentane & 1-hexene & isoprene & isoprene & isoprene \\
\hline 1-Butene & cis-2-butene & cis-2-butene & toluene & cis-2-butene \\
\hline Benzene & cis-2-pentene & $n$-pentane & cis-2-butene & trans-2-pentene \\
\hline 3-Methylpentane & isopentane & trans-2-pentene & trans-2-pentene & 1-hexene \\
\hline 1-Hexene & $n$-pentane & 1-hexene & 1-hexene & toluene \\
\hline Isoprene & isobutane & cis-2-pentene & $n$-hexane & cis-2-pentene \\
\hline$n$-Heptane & toluene & $(m+p)$-xylene & cis-2-pentene & $n$-hexane \\
\hline trans-2-Butene & 1-pentene & 1-pentene & 1-pentene & 1-pentene \\
\hline Methylcyclopentane & $n$-hexane & $n$-hexane & 2-methylpentane & 2-methylpentane \\
\hline $\begin{array}{l}\text { Accumulated mass } \\
\text { fraction }=81 \% \text { of total } \\
\text { VOC mass abundance }\end{array}$ & $\begin{array}{c}\text { accumulated } \\
\text { reactivity }=79 \% \text { of } \\
\text { kinetic reactivity }\left(\mathrm{k}_{\mathrm{OH}}\right)\end{array}$ & $\begin{array}{c}\text { accumulated } \\
\text { reactivity }=80 \% \text { of } \\
\text { total incremental reactivity } \\
(\mathrm{MIR}) \\
\end{array}$ & $\begin{array}{c}\text { accumulated } \\
\text { reactivity }=81 \% \text { of } \\
\text { total incremental reactivity } \\
(\mathrm{MOIR})\end{array}$ & $\begin{array}{c}\text { accumulated } \\
\text { reactivity }=81 \% \text { of } \\
\text { total incremental reactivity } \\
\text { (EBIR) }\end{array}$ \\
\hline \multicolumn{5}{|c|}{ Deodoro zone } \\
\hline$n$-Butane & 1-butene & 1-butene & $n$-butane & $n$-butane \\
\hline Isobutane & isoprene & $n$-butane & 1-butene & 1-butene \\
\hline Isopentane & trans-2-butene & toluene & isopentane & isopentane \\
\hline$n$-Pentane & trans-2-pentene & trans-2-butene & isobutane & isobutane \\
\hline Toluene & cis-2-butene & isopentane & $n$-pentane & $n$-pentane \\
\hline$n$-Hexane & styrene & isobutane & toluene & trans-2-butene \\
\hline 1-Butene & $n$-butane & cis-2-butene & trans-2-butene & cis-2-butene \\
\hline 2-Methylpentane & 1-hexene & $n$-pentane & cis-2-butene & toluene \\
\hline Benzene & isopentane & trans-2-pentene & trans-2-pentene & trans-2-pentene \\
\hline 3-Methylpentane & $n$-pentane & isoprene & isoprene & isoprene \\
\hline$n$-Heptane & cis-2-pentane & 1-hexene & 1-hexene & 1-hexene \\
\hline Methylcyclopentane & toluene & cis-2-pentene & $n$-hexane & $n$-hexane \\
\hline trans-2-Butene & isobutane & $(m+p)$-xylene & 2-methylpentane & 2-methylpentane \\
\hline 1-Hexene & 1-pentene & $n$-hexane & 1-pentene & 3-methylpentane \\
\hline cis-2-Butene & $n$-hexane & 1-pentene & 3-methylpentane & 1-pentene \\
\hline $\begin{array}{l}\text { Accumulated mass } \\
\text { fraction }=84 \% \text { of total } \\
\text { VOC mass abundance }\end{array}$ & $\begin{array}{l}\text { accumulated } \\
\text { reactivity }=81 \% \text { of kinetic } \\
\text { reactivity }\left(\mathrm{k}_{\mathrm{OH}}\right)\end{array}$ & $\begin{array}{c}\text { accumulated } \\
\text { reactivity }=84 \% \text { of } \\
\text { total incremental reactivity } \\
\text { (MIR) }\end{array}$ & $\begin{array}{c}\text { accumulated } \\
\text { reactivity }=84 \% \text { of } \\
\text { total incremental reactivity } \\
(\text { MOIR) }\end{array}$ & $\begin{array}{c}\text { accumulated } \\
\text { reactivity }=87 \% \text { of } \\
\text { total incremental reactivity } \\
(\text { EBIR) }\end{array}$ \\
\hline
\end{tabular}

MIR: maximum incremental reactivity; MOIR: maximum ozone incremental reactivity; EBIR: equal benefit incremental reactivity; VOC: volatile organic compound.

1-hexene and trans- and cis-2-butene were within the top 15 compounds in the five ranking lists. This list of most abundant compounds is very similar to that of Tijuca in 2016, except for isoprene and cis-2-butene. The high concentrations of isoprene in Tijuca are a consequence of the proximity to the Tijuca Forest and the Sumare Mountain, which is covered by tropical rainforest. ${ }^{26}$ Isoprene, trans- and cis-2-pentene, 1-pentene and xylenes were only important when considering the reactivity scales.
Data obtained in 2015 for the same location in Tijuca showed a $\mathrm{VOC} / \mathrm{NO}_{\mathrm{x}}$ ratio of $8.86 .{ }^{32}$ For the present conditions in 2016, using the total VOC concentration in units of ppmC and $\mathrm{NO}_{x}$ concentrations determined in the automatic monitoring station in ppm units, the VOC/NO $\mathrm{Na}_{\mathrm{x}}$ ratio was lower (7.34). Both results show that ozone formation is controlled by VOCs, which explained the lower ozone concentration values in 2016, since, as previously shown, total VOC levels were lower in 2016. 
To assess these differences, individual data for the 21 main VOCs and all samples were analyzed using non-parametric tests to verify whether the null hypothesis that all populations have identical distribution functions was valid. Using a Kruskal-Wallis non-parametric analysis of variance (ANOVA), the calculated $p$-value for the samples collected in Tijuca (2015 and 2016) and Deodoro (2016) was 0.04 , indicating that the null hypothesis can be rejected and suggesting that there are significant differences between the samples. When samples for Tijuca and Deodoro in 2016 are considered, the $p$-value is 0.84 , indicating that there is no reason to conclude that the sample distributions are different. If samples for Tijuca from 2015 and 2016 are analyzed, the $p$-value is 0.15 . It is commonly accepted that the null hypothesis can be rejected for $p$-values $<0.05$, but cutoff values of $<0.10$ may also be adopted. For the present data, a $p$-value of 0.15 suggests that there were some differences between the samples collected in the two years. These results suggest that the emissions sources in Tijuca and Deodoro were similar during the Olympic Games while differences, in Tijuca between 2015 and 2016, were appreciable.

\section{Criteria pollutant concentrations}

AQIs should be calculated based on the highest index for several compounds $\left(\mathrm{PM}_{10}, \mathrm{SO}_{2}, \mathrm{O}_{3}, \mathrm{NO}_{2}\right.$ and $\left.\mathrm{CO}\right)$. Nevertheless, in the Olympic stations, the AQIs were estimated using ozone 1-hour maximum concentrations. ${ }^{16}$ For ozone, the good (0-50), moderate (51-100) and unhealthy (101-200) indexes correspond to concentrations of $<80$, 81-160, and 161-200 $\mu \mathrm{g} \mathrm{m}^{-3}$ (1-hour mean), respectively.

The AQIs determined, by INEA, ${ }^{16}$ in the Campo dos Afonsos (Deodoro) and Maracanã Olympic monitoring stations in August 2015 and August 2016 are displayed in the SI section (Figure S3). Lines indicating good (0-50) and moderate (51-100) values are also included in Figure S3 and these values are detailed in Table S1.

In August 2015, the AQIs in the INEA stations of Campo dos Afonsos (Deodoro) and Maracanã, were moderate on 63 and $32 \%$ of the reported days, respectively, indicating that ozone concentrations were in the interval of 81-160 $\mu \mathrm{g} \mathrm{m}^{-3}$; on one day (August 30), the national air quality standard $\left(160 \mu \mathrm{g} \mathrm{m}^{-3}\right)$ was exceeded. It is worth noting that the AQI was reported for only 20 and $67 \%$ of the days for the Deodoro and Maracanã stations, respectively. The high ozone concentrations in Campo dos Afonsos were related to the proximity of Brazil Avenue, which is considered the main source of vehicular pollutants in Rio de Janeiro. ${ }^{11,33}$ In August 2016, INEA reported that in the Campo dos Afonsos and Maracanã stations, there were only one and two days, respectively, when the value of $80 \mu \mathrm{g} \mathrm{m}^{-3}$ was exceeded. ${ }^{16}$ The lower ozone levels could be attributed to severe traffic restrictions in Brazil Avenue and other important circulation routes in the west and north area of the city and in the proximity of Maracanã Stadium, mainly during the Olympic Games.

Criteria pollutant concentration data collected from the automatic monitoring station, operated by SMAC, ${ }^{5}$ located in Saens Peña Square, Tijuca, in the Olympic area of Maracanã, were also analyzed. Data for $\mathrm{PM}_{10}, \mathrm{CO}, \mathrm{NO}_{2}$ and ozone concentrations were displayed in the form of box-plots. Data for primary pollutants $\mathrm{PM}_{10}$ and $\mathrm{CO}$ are presented in Figures S4 and S5 in the SI section. Results for $\mathrm{NO}_{2}$ and ozone are shown in Figures 1 and 2.

Primary pollutants, $\mathrm{PM}_{10}$, and $\mathrm{CO}$ concentrations were in general lower in 2016 as a consequence of the restrictions on vehicular flux. The higher $\mathrm{NO}_{2}$ concentrations during the Olympic Games (August 2016), mainly after midday, could be attributed to the change in fleet profile, with an increase in the vehicular flux in the afternoon due to the circulation of tourists and several entertainment activities in the vicinity of the monitoring station. It is noted that buses are the main source of nitrogen oxide emissions in the Rio de Janeiro Metropolitan Area. ${ }^{33}$ The automatic monitoring station is installed in an area with several bus stops and a subway station, which is, in general, busy on week days during rush hour (7:00-9:00 a.m.) due to the opening of schools and commerce in the early morning. In August 2016, due to the school holidays and the Olympic Games, the flux of vehicles and people peaked after 9:00 a.m. Ozone concentrations were also lower in August and September 2016.

The AQIs reported by SMAC for this station in August 2015 showed that on $22.5 \%$ of the days, ozone concentrations were $81-160 \mu \mathrm{g} \mathrm{m}^{-3}$ and that the national air quality standard $\left(160 \mu \mathrm{g} \mathrm{m}^{-3}\right)$ was also exceeded on August 31. On $16 \%$ of the days in August 2016, ozone concentrations were $81-160 \mu \mathrm{g} \mathrm{m}^{-3}$, leading to a moderate AQI. When all the pollutants are considered for the calculation of the AQI $\left(\mathrm{NO}_{2}, \mathrm{O}_{3}, \mathrm{CO}, \mathrm{PM}_{10}, \mathrm{SO}_{2}\right)$, it is observed that the numbers of days with a moderate air quality were 8 (26.7\% of the days) and $13(43.3 \%$ of the days) for August 2015 and August 2016, respectively, due to the higher $\mathrm{NO}_{2}$ levels in 2016. For this compound, a moderate AQI (51-100) corresponds to concentrations from 101 to $320 \mu \mathrm{g} \mathrm{m}^{-3}$. In August 2015, the mean $\mathrm{NO}_{2}$ maximum concentration was 63.4, while it was $100.9 \mu \mathrm{g} \mathrm{m}^{-3}$ in 2016 (1-hour mean). For ozone, its mean maximum 1-hour concentrations in 2015 and 2016 were 72.5 and $70.1 \mu \mathrm{g} \mathrm{m}^{-3}$, respectively. It is worth noting that on August 17, 18 and 29, 2016, ozone maximum 1-hour concentrations were 

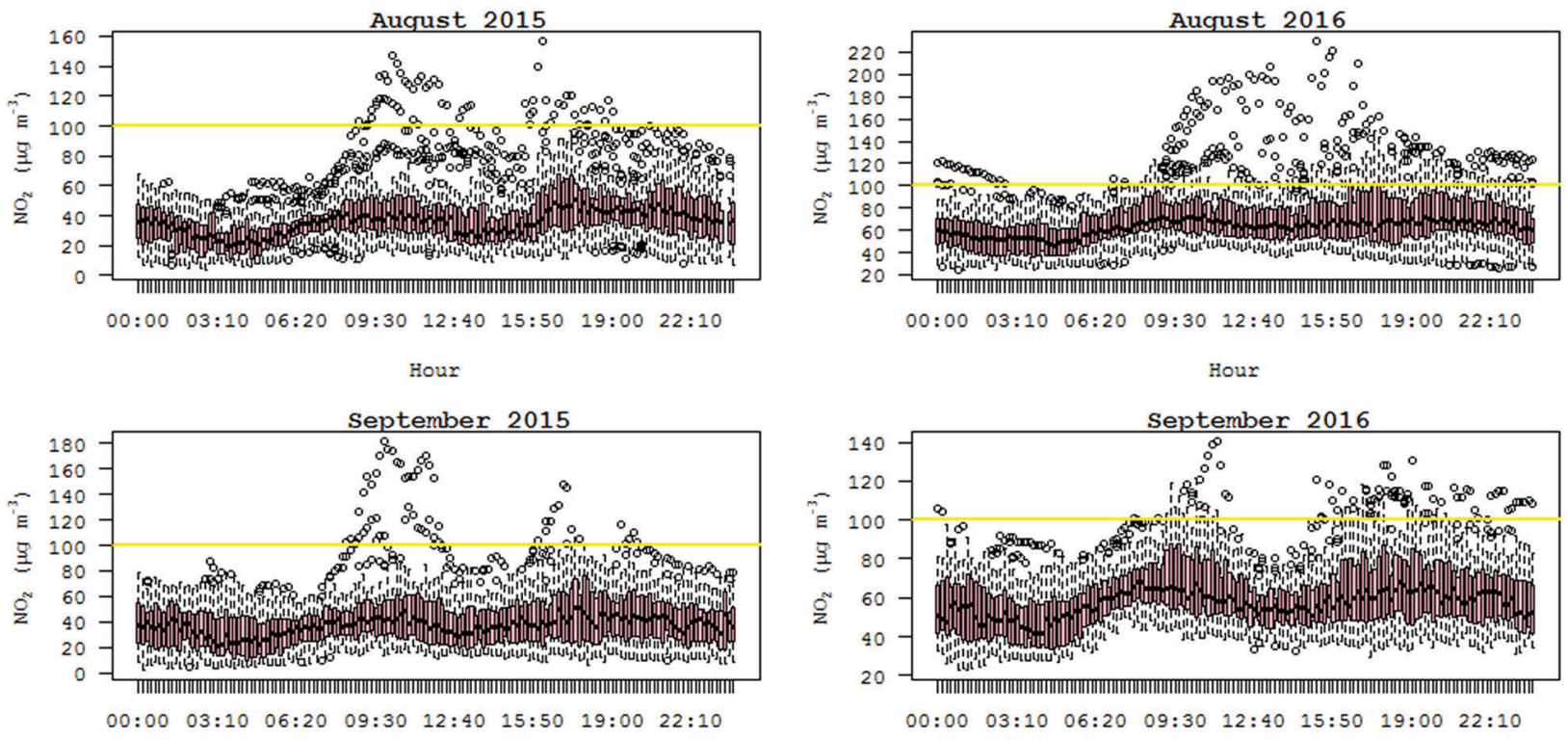

Hour

Hour

Figure 1. $\mathrm{NO}_{2}$ concentrations determined at the Tijuca monitoring station in August and September of 2015 and 2016.
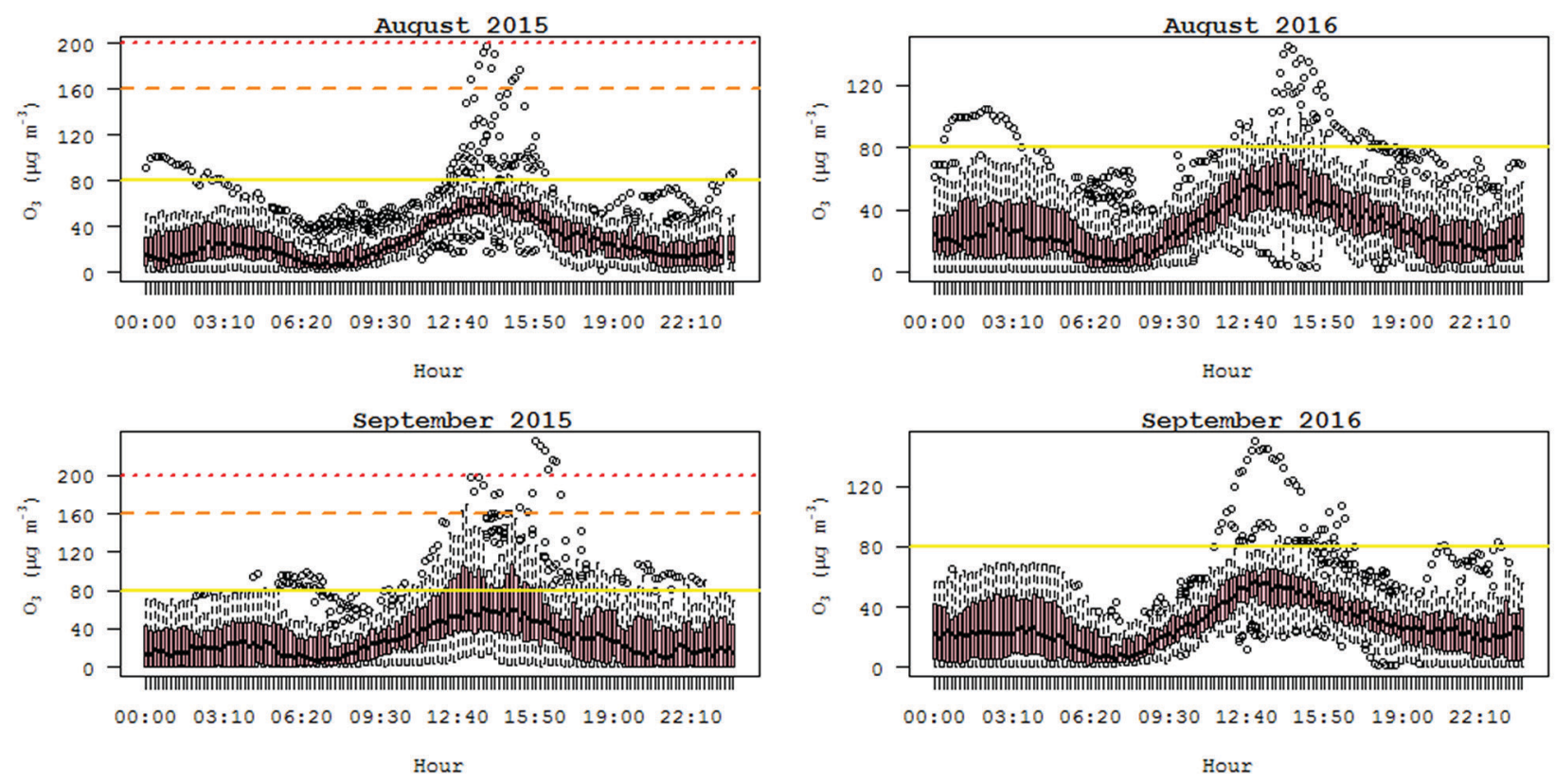

Figure 2. Ozone concentrations determined at the Tijuca monitoring station in August and September of 2015 and 2016.

higher than $100 \mu \mathrm{g} \mathrm{m}^{-3}$. When these three days are not considered, the mean value was $65.9 \mu \mathrm{g} \mathrm{m}^{-3}$. The means of the AQIs for August 2015 and August 2016 were 49.4 and 50, respectively, showing that, in general, no improvement in air quality was observed in this area during the Olympic Games.

Results obtained from the Tijuca station showed that the AQIs calculated considering only ozone concentrations could be underestimated and stressed the importance of monitoring and calculating AQIs on the basis of all criteria pollutants. ${ }^{6}$ The indexes reported for Campo dos Afonsos (Deodoro) and Maracanã zones were, in general, $<50$ during the Olympic Games. However, as the computation did not include $\mathrm{NO}_{2}$, the indexes might not adequately reflect the air quality situation. They also showed that the combined results of the vehicular flux restrictions and the use of a limited number of criteria pollutants to report the air quality led to AQIs in the intervals 0-50 (good) and 51-100 (moderate) in spite of concentrations being frequently high when considering WHO guidelines. ${ }^{9}$

No AQI data were reported by the Tijuca automatic monitoring station during the Paralympic Games (September 7-18). During the period of September 1-7, 
the mean AQI was 47 , and the AQI was moderate (> 50) on two days.

\section{Simulated ozone concentrations}

A detailed modeling, taking into account meteorological parameters in some detail and the transport of pollutants from other areas, is not possible since data for Rio de Janeiro are limited to a few determinations in the air quality monitoring stations. Then, to further explore these conclusions, the ozone concentrations were modeled using the OZIPR trajectory model and the SAPRC photochemical mechanism to infer the effect of VOCs concentrations, temperature and solar radiation. ${ }^{41-47}$ This model has been fully described in earlier studies. ${ }^{34,35}$ A representative or base case had been designed, on the basis of experimental VOCs concentrations as well as air quality monitoring station information for 2015, and discussed in a previous study. ${ }^{28,32}$ Briefly, the initial concentrations of $\mathrm{CO}$ and $\mathrm{NO}_{\mathrm{x}}$ were calculated using the average hourly concentrations, which were measured at 6:30 a.m. by the monitoring station. The speciation and initial total VOC concentration values, used for the modeling were experimentally obtained with the TO- 15 method, ${ }^{27}$ as previously described. Formaldehyde and acetaldehyde were determined in the same location using TO-11A method, as described by Silva et al..$^{28}$ The $\mathrm{CO}$ and $\mathrm{NO}_{\mathrm{x}}$ emissions were set using the measured ambient concentrations as a rough guide. The $\mathrm{VOC} / \mathrm{NO}_{\mathrm{x}}$ emission ratio was estimated using experimental ambient data, which were obtained at the studied location, and data for emission inventories. ${ }^{33,48,49}$ Using this previous model, the impact of changes in VOCs concentrations and speciation was estimated.

For the same meteorological conditions and considering the total mean VOC concentration and speciation for each monitoring period, calculated mean maximum ozone levels were approximately 1.5 higher in 2015 . However, when the higher total VOC concentration determined on August 17, 2016, was considered, the ozone maximum for 2015 was only 1.2 times higher.

Solar radiation during August 2016 was determined by SMAC in Maracanã zone. For the three days with higher ozone concentrations (August 17, 18 and 29), solar radiation at midday was 1,4 and $15 \%$, respectively, higher than the medium value for the month and 2-13\% lower than the maximum value. Simulated ozone concentrations using the base model, also showed a dramatic dependence on solar radiation. When the incident solar radiation was decreased by $20 \%$, the maximum calculated ozone concentration was approximately 50\% lower than the concentration of the base case.
The maximum temperatures in these three days were abnormally high for winter $\left(33.2,32.2\right.$ and $38.3{ }^{\circ} \mathrm{C}$, for August 17, 18 and 29, respectively), in comparison to the average maximum value for 30 years $\left(25^{\circ} \mathrm{C}\right) . .^{50}$ Simulated results showed that an increase of $10{ }^{\circ} \mathrm{C}$ results in an increase of $24 \%$ in ozone maximum concentration.

Although considered very simple, the model supports the previous conclusion that lower ozone concentrations during the Olympic Games were due to the decrease in VOC levels and that the highest values determined on August 17, 18 and 29, 2016, may be due to the combined effect of higher VOC concentrations, temperatures and solar radiation. Also, wind speeds during those days were $\leq 0.8 \mathrm{~m} \mathrm{~s}^{-1}$, which might difficult pollutants dispersion.

No $\mathrm{NO}_{\mathrm{x}}$ levels or VOC concentrations determined in previous years for Deodoro are available to be compared with the present results. Meteorological parameters were not reported for Campo dos Afonsos (Deodoro zone) monitoring station.

The results obtained in the studied areas show that the drastic emission measures adopted during the Olympic Games were successful during that period, but considering that the emission control was restricted to the Olympic and Paralympic period, air quality improvement was local and time limited. More stringent control of emissions would be needed in the future in order to improve the air quality, especially primary pollutants $\left(\mathrm{NO}_{2}, \mathrm{PM}_{2.5}\right.$ and $\left.\mathrm{PM}_{10}\right)$ and ozone, which can reach higher concentrations under adverse meteorological conditions. Actions to improve air quality require significant investment in monitoring to ensure that data are complete, consistent and comparable. Integrated frameworks for maintaining long-term monitoring programs supported by a network of laboratories and monitoring stations should provide these data. ${ }^{51}$ Also, in the case of ozone, precursors should be addressed. Other non-criteria pollutants, such as $\mathrm{PM}_{2.5}$, should be included in the monitoring and informed to the population..$^{10,52}$ The implementation of a more efficient mass transport network, the expansion of the underground with a sustainable route plan and the modernization of the fleet, replacing diesel buses by low emissions equivalents, are actions that could have a positive impact on the reduction of $\mathrm{NO}_{2}$ and particulate matter. These conclusions are similar to those obtained in other Olympic Games. ${ }^{40,53-57}$

The so-called "Olympic legacy" is a fundamental commitment of the Olympic Movement to create a set of environmental, social and economic legacies that can change a community and a nation. The clean air legacy was part of the promises of the Rio 2016 Games, but, as a consequence of the limited investment, complete and permanent solutions were not achieved. During and after 
the Games several scientists and national and international journalists discussed the lack of complete air quality data available to athletes and population in general.

\section{Conclusions}

The concentrations of VOCs and criteria pollutants determined in two Olympic zones, during the Olympic Games, showed that preventive policies adopted by the Government to reduce emissions were successful in decreasing the concentrations of the primary pollutants $\mathrm{CO}, \mathrm{PM}_{10}$ and VOCs, leading to a decrease in mean ozone levels. However, AQIs were not dramatically reduced due to the increase in $\mathrm{NO}_{x}$ emissions and isolated events of higher ozone levels. The reduced number of VOC samples and the limited information collected in the air quality monitoring stations difficult a complete analysis of ozone levels and a detailed inter-year comparison.

Finally, it should be stressed that Brazilian air quality allowable standards are clearly high in comparison to WHO guidelines, and the combined results of adopted air quality indexes and the use of a restricted number of criteria pollutants to report the air quality lead to AQIs in the intervals of 0-50 (good) and 50-100 (moderate) despite concentrations being frequently high in terms of WHO guidelines. The adoption of WHO AQG, the calculation of AQIs using all the criteria pollutants and the determination of $\mathrm{PM}_{2.5}$ and VOCs should be recommended during the Olympic candidature process, the election of the host city and the Olympic Games.

\section{Supplementary Information}

Map of the city with the sampling locations; wind rose calculated for August and September 2016, in Tijuca (Rio de Janeiro); daily air quality indexes determined in the Olympic monitoring stations Campo dos Afonsos and Maracanã (August 2015 and 2016); $\mathrm{PM}_{10}$ concentrations determined at the Tijuca monitoring station in August and September of 2015 and 2016; CO concentrations determined at the Tijuca monitoring station in August and September of 2015 and 2016; air quality standards; literature data; and air quality indexes adopted in Brazil are available free of charge at http://jbcs.sbq.org.br as PDF file.

\section{Acknowledgments}

The authors acknowledge data provided by the Municipal Department of the Environment (SMAC) and financial support from the Fundação de Amparo à Pesquisa do Rio de Janeiro (FAPERJ), the Coordenação de Aperfeiçoamento de Pessoal de Nível Superior (CAPES) and the National Counsel of Technological and Scientific Development (CNPq). They also acknowledge the support of Luane Lima da Silva in the sampling campaign in the Deodoro zone.

\section{References}

1. https://cidades.ibge.gov.br/, accessed on February 28, 2018.

2. https://www.olympic.org/rio-2016, accessed on February 17, 2018.

3. http://www.brasil2016.gov.br/en/legacy/infraestrutura, accessed on February 28, 2018.

4. http://www.inea.rj.gov.br/Portal/MegaDropDown/ Monitoramento/Monitoramentodoar-EmiQualidade/Qualidoar/ index.htm\&lang=, accessed in May 2018.

5. http://www.rio.rj.gov.br/web/smac/monitorar-rio1, accessed in May 2018.

6. CONAMA; Resolução CONAMA, No. 003/1990 Dispõe sobre Padrões de Qualidade do Ar, Previstos no PRONAR, Diário Oficial da União (DOU), Brasília, 1990, Seção 1, p. 1593715939. Available at http://www.mma.gov.br/port/conama/ legiabre.cfm?codlegi=100, accessed in May 2018.

7. https://www.epa.gov/criteria-air-pollutants/naaqs-table, accessed in May 2018.

8. http://ec.europa.eu/environment/air/quality/standards.htm, accessed in May 2018.

9. World Health Organization; WHO Air Quality Guidelines for Particulate Matter, Ozone, Nitrogen Dioxide and Sulfur Dioxide, WHO, Geneva, 2006. Available at http://apps.who.int/iris/ bitstream/10665/69477/1/WHO_SDE_PHE_OEH_06.02_eng. pdf, accessed in May 2018.

10. Godoy, M. L. D. P.; Almeida, A. C.; Tonietto, G. B.; Godoy, J. M.; J. Braz. Chem. Soc. 2018, 29, 499.

11. Ventura, L. M. B.; Ramos, M. B.; Fernandes, L. C.; Soares, C. M.; Santos, J. O.; Ineana 2016, 4, 6. http://www.inea.rj.gov. br/cs/groups/public/@inter_vpres_geiat/documents/document/ zwew/mtmz/ edisp/inea0133565.pdf, accessed in May 2018.

12. Kuklinska, K.; Wolska, L.; Namiensnik, J.; Atmos. Pollut. Res. 2015, 6, 129.

13. Krzyzanowski, M.; Cohen A.; Air Qual., Atmos. Health 2008 , 1,7 .

14. Rich, D. Q.; Kipen, H. M.; Huang, W.; Wang, G.; Zhu, P.; Strickland, P. O.; Hu, M.; Philipp, C.; Diehl, S. R.; Lu, S. E.; Tong, J.; Gong, J.; Thomas, D.; Zhu, T.; Zhang, J.; JAMA, J. Am. Med. Assoc. 2012, 307, 2068.

15. McCarthy, M.; Ravelli, R. J.; Sinclair-Williams, M.; Eur. J. Public Health 2010, 20, 619.

16. http://www.inea.rj.gov.br/Portal/MegaDropDown/ Monitoramento/Monitoramentodoar-EmiQualidade/Qualidoar/ Boletimdiriodaqualidoar/index.htm\&lang=, accessed in May 2018. 
17. Kampa, M.; Castanas, E.; Environ. Poll. 2008, 151, 362.

18. Liu, J. F.; Mu, Y. J.; Zhang, Y. J.; Zhang, Z. M.; Wang, X. K.; Liu, Y. J.; Sun, Z. Q.; Sci. Total Environ. 2009, 408, 109.

19. Atkinson, R.; Atmos. Environ. 2000, 34, 2063.

20. Guarieiro, L. L. N.; Amparo, K. K. S.; Figueirêdo, I. S.; de Andrade, J. B.; Rev. Virtual Quim. 2017, 9, 2082.

21. Finlayson-Pitts, B. J.; Pitts Jr., J. N.; Chemistry of the Upper and Lower Atmosphere - Theory, Experiments and Applications; Elsevier Inc.: San Diego, CA, USA, 2000.

22. Siqueira, C. Y. S.; Lemos, M. V. P.; Araujo, B. C. C.; de Oliveira, R. R. P. E.; Gil, R. A. S. S.; de Aquino Neto, F. R.; Microchem. J. 2017, 133, 638.

23. Tsuruta, F.; Carvalho, N. J.; Silva, C. M.; Arbilla, G.; J. Braz. Chem. Soc. 2018, 29, 1291.

24. http://inside.fei.org/system/files/RIO\%20Weather $\% 20$ forecast_0.pdf, accessed in May 2018.

25. http://alertario.rio.rj.gov.br/download/, accessed in May 2018. 26. http://www.rio.rj.gov.br/dlstatic/10112/3252594/4114836/ RelatorioMonitorar20112012.pdf, accessed in March 16, 2018.

27. United States Environmental Protection Agency (US EPA); Compendium of Methods for the Determination of Toxic Organic Compounds in Ambient Air - Second Edition; US EPA, Cincinnati, OH, USA, 1999. Available at https://www3. epa.gov/ttnamti1/files/ambient/airtox/tocomp99.pdf, accessed in May 2018.

28. Silva, C. M.; da Silva, L. L.; Corrêa, S. M.; Arbilla, G.; Bull. Environ. Contam. Toxicol. 2016, 97, 781.

29. Silva, C. M.; Souza, E. C. C. A.; da Silva, L. L.; Oliveira, R. L.; Arbilla, G.; Corrêa, S. M.; Quim. Nova 2016, 39, 1245.

30. http://ar.cetesb.sp.gov.br/padroes-de-qualidade-do-ar/, accessed in May 2018.

31. https://www.R-project.org/, accessed in May 2018.

32. Silva, C. M.; da Silva, L. L.; Corrêa, S. M.; Arbilla, G.; Atmos. Pollut. Res. 2018, 9, 369.

33. Instituto Estadual do Ambiente (INEA); Inventário - Emissões de Fontes Veiculares - Região Metropolitana do Rio de Janeiro - Ano-Base 2013; INEA, Rio de Janeiro, Brazil, 2016. http:// www.inea.rj.gov.br/cs/groups/public/@inter_vpres_geiat/ documents/document/zwew/mti3/ edisp/inea0127611.pdf, accessed in May 2018.

34. Martins, E. M.; Nunes, A. C. L.; Correa, S. M.; J. Braz. Chem. Soc. 2015, 26, 1967.

35. Geraldino, C. P.; Martins, E. M.; Silva, C. M.; Arbilla, G.; Bull. Environ. Contam. Toxicol. 2017, 98, 632.

36. Martins, E. M.; Arbilla, G.; Bauerfeldt, G. F.; de Paula, M.; Chemosphere 2007, 67, 2096.

37. Rodrigues, F.; Milas, I.; Martins, E. M.; Arbilla, G.; Bauerfeldt, G. F.; de Paula, M.; J. Braz. Chem. Soc. 2007, 18, 342.

38. Souza, E. C.; Oliveira, R. L.; Arbilla, G.; Atmósfera 2016, 29 , 197.
39. Correa, S. M.; Arbilla, G.; Atmos. Environ. 2006, 40, 6821.

40. Wang, T.; Nie, W.; Gao, J.; Xue, L. K.; Gao, X. M.; Wang, X. F.; Qiu, J.; Poon, C. N.; Meinardi, S.; Blake, D.; Wang, S. L.; Ding, A. J.; Chai, F. H.; Zhang, Q. Z.; Wang, W. X.; Atmos. Chem. Phys. 2010, 10, 7603.

41. Carter, W. P. L.; SAPRC Atmospheric Chemical Mechanism and VOC Reactivity Scales. Available at http://www.engr.ucr. edu/ carter/SAPRC/, accessed in May 2018.

42. Carter, W. P. L.; Atmos. Environ. 2010, 44, 5324.

43. Gery, M. W.; Crouse, R. R.; User's Guide for Executing OZIPR; US EPA, Research Triangle Park, NC, USA, 1990. Available at https://www3.epa.gov/scram001/userg/other/ozipr.pdf, accessed in May 2018.

44. Tonnessen, G. S.; User's Guide for Executing OZIPR Version 2.0; US EPA, Research Triangle Park, NC, USA, 2000.

45. Do, W.; Lee, H.; Jung, W.; J. Environ. Sci. 2007, 16, 985.

46. Orlando, J. P.; Alvim, D. S.; Yamazaki, A.; Corrêa, S. M.; Gatti, L. V.; Sci. Total Environ. 2010, 408, 1612.

47. Alvim, D. S.; Gatti, L. V.; Corrêa, S. M.; Chiquetto, J. B.; Rossatti, A. P.; dos Santos, M. H.; Yamasaki, A.; Orlando, J. P.; Santos, G. M.; Air Qual., Atmos. Health 2017, 10, 421.

48. Ministério do Meio Ambiente; Inventário Nacional de Emissões Atmosféricas por Veículos, Ministério do Meio Ambiente, Brasília, 2011. Available at www.mma.gov.br/estruturas/163/_ publicacao/163_publicacao27072011055200.pdf, accessed on March 19, 2018.

49. Vivanco, M. G.; Andrade, M. F.; Atmos. Environ. 2006, 40, 1189.

50. http://www.inmet.gov.br/portal/index.php?r=bdmep/bdmep, accessed in May 2018.

51. Hsu, A.; Reuben, A.; Shindell, D.; de Sherbinin, A.; Levy, M.; Atmos. Environ. 2013, 80, 561.

52. Ventura, L. M. B.; Mateus, V. L.; de Almeida, A. C. S. L.; Wanderley, K. B.; Taira, F. T.; Saint'Pierre, T. D.; Gioda, A.; Air Qual., Atmos. Health 2017, 10, 845.

53. McCartney, G.; Thomas, S.; Thomson, H.; Scott, J.; Hamilton, V.; Hanlon, P.; Morrison, D. S.; Bond, L.; BMJ [Br. Med. J.] 2010, 340, C2369.

54. Wang, T.; Xie, S.; Atmos. Environ. 2009, 43, 5682.

55. Wang, M.; Zhu, T.; Zheng, J.; Zhang, R. Y.; Zhang, S. Q.; Xie, X. X.; Han, Y. Q.; Li, Y.; Atmos. Chem. Phys. 2009, 9, 8247.

56. Wang, W. T.; Primbs, T.; Tao, S.; Simonich, S. L. M.; Environ. Sci. Technol. 2009, 43, 5314.

57. Wang, X.; Westerdahl, D.; Chen, L. C.; Wu, Y.; Hao, J. M.; Pan, X. C.; Guo, X. B.; Zhang, K. M.; Atmos. Environ. 2009, 43, 4535 .

Submitted: March 18, 2018

Published online: May 22, 2018 